\title{
The Impacts of Entrepreneurial Education and Entrepreneurial Implementation on Entrepreneurial Intention: Evidences from Public University in the Northern Malaysia
}

\author{
Saraih, U. N., Ibnu Ruslan, R., Ali, M. A., Mohd Suffian, M. S. Z.
}

\begin{abstract}
This study aims to identify the impacts of entrepreneurial education and entrepreneurial implementation on entrepreneurial intention among undergraduate students from one of public university in the Northern Region of Malaysia. The theoretical framework for this study is developed based on the literature review. In this study, 488 usable respondents are obtained by using a survey method. Based on the results, it is found that entrepreneurial education and entrepreneurial implementation have significant impact towards students' entrepreneurial intention. The findings presented that students in this institution have moderately high levels of entrepreneurial education (mean=3.70), entrepreneurial implementation (mean=3.12) and entrepreneurial intention (mean=3.64). Results also presented that entrepreneurial education is significantly related to entrepreneurial intention $(\beta=.55, p=.00)$. Other factor which is entrepreneurial implementation also significantly related to entrepreneurial intention $(\beta=.52, p=.00)$. These study findings will be fruitful for Ministry of Higher Education (MoHE) including the policy makers and academicians to identify the factors which can create the impact on the university students to be involved into entrepreneurship. Next, the results of this study will provide a guide for the university managements on the formulation and implementation of policies. This knowledge on entrepreneurial education and implementation may help the country to eventually reduce the Malaysian unemployment rate. Last but not least, several directions for the future study have been suggested.
\end{abstract}

Index Terms: Entrepreneurial education, entrepreneurial implementation, entrepreneurial intention.

\section{INTRODUCTION}

The importance of entrepreneurship has been the center of worldwide attention including Malaysia. The increasing interest of entrepreneurship in Malaysia can be seen in the current developments, such as globalization and the emergence of knowledge-based industries. Entrepreneurship is seen as a possible solution to global competition and to build a knowledge-based economy.

In the local context, the Ministry of Higher Education or MoHE tries to switch and focus on entrepreneurship as a gateway to the employment creation in order to stabilize the

Revised Manuscript Received on April 19, 2019.

Ummi Naiemah Saraih, School of Business Innovation \& Technopreneurship, Universiti Malaysia Perlis, Kangar, Perlis, Malaysia.

Ruswahida Ibnu Ruslan, Centre for Industrial \& Government Collaboration, Universiti Malaysia Perlis, Kangar, Perlis, Malaysia.

Muhammad Ahmar Ali, School of Business Innovation \& Technopreneurship, Universiti Malaysia Perlis, Kangar, Perlis, Malaysia.

Muhammad Sufino Zuhaily Mohd Suffian, School of Business Innovation \& Technopreneurship, Universiti Malaysia Perlis, Kangar, Perlis, Malaysia. economies [1]. Unemployment among university graduates remains a crucial issue in Malaysia. Given that, there is a need to study on some factors which able to increase the level of entrepreneurial intention especially among the undergraduate students in Malaysia since the gained knowledge may contribute to solve the problem of unemployment. According to [2] intentions based models provide practical insight to any planned behaviour, thus intentions are the single best predictor of any planned behaviour, including entrepreneurship. This imply to the claim that entrepreneurial intention is the best predictor of entrepreneurial behaviour or entrepreneurial action of creating a new business.

The introduction of entrepreneurial education in the Malaysian universities was done to expose students for career opportunities in business. Malaysia Vision 2020 lays the foundation for the nation to achieve the status of a developed country by the year 2020, putting much emphasis in education in the nation's effort to build a knowledgebased economy [3]. As stated by [4], university education has been acknowledged as a primary mechanism for the creation of a knowledge economy and the development of human capital all over the world. Thus, the management in all universities including Malaysia needs to play a vital role towards the entrepreneurial education to increase the human development and to build the knowledge-based economy especially in producing the future entrepreneurs. In the recent years, [5] claimed that although several empirical evidences recorded that educational courses or programmes have a positive impact on entrepreneurism (eg.[6]), however others have produced evidences to suggest that the relationship between entrepreneurship education and entrepreneurism is negative or insignificant (eg. [7],[8]). Thus, the findings in this area remain inconsistent and further studies are required. Therefore, this study attempts to contribute for a further knowledge on the relationship between entrepreneurial education and entrepreneurial intention in the context of the Malaysian public university.

Equally important, entrepreneurial implementation appears as the other essential factor which enable to create a positive impact on entrepreneurial intention. Education alone may not be enough if the implementation upon entrepreneurial is not well practiced. Thus, this becomes the root why entrepreneurial implementation needs to be studied 
International Conference on Recents Advancements in Engineering and Technology (ICRAET-18) |15th and 16th March 2019|Siddhartha Institute of Technology \& Sciences, Telangana, India.

to provide a body of knowledge on its impact of students' entrepreneurial intention. Moreover, lack evidences are reported on the relationship between these two variables in the local context. Foreign study has been done to explore the relationship between entrepreneurial education and entrepreneurial implementation intention among students in Nigeria [4]. However, this study is different from the mentioned study because this study attempts to examine the impact of entrepreneurial implementation towards entrepreneurial intention among students in one of the Malaysian public university. Moreover, different culture will play some sort of role which may create any impact which need to be revealed.

\section{LITERATURE REVIEW}

The objective of this section is to provide the related literature based on past empirical evidences. Specifically, in the first place, this section reviews the importance of entrepreneurial intention. In the second stage, discussion on the concept of entrepreneurial education as well as entrepreneurial implementation has been touched. Next, related empirical studies on the connection between entrepreneurial education and entrepreneurial implementation towards entrepreneurial intention have been discussed to develop the research hypotheses.

\section{A. Entrepreneurial Intention}

Unemployment issues among graduates have been raised concern by policy makers and academicians [9]. Fresh graduates may possess a good kind of knowledge, skills and ability to start-up their own business once they are graduated. However, does this make them choose to be a job seeker or job creator after the graduation? Although they have been placed in the entrepreneurial programme; however, does this make them possess a high intent to become the entrepreneurs once they have been graduated. As such, it is important to determine on several factors which might be able to create the impact on their intention to become the job creator, or in other words to be the entrepreneurs while they are still in the university's environment. Since the early 1990s, different scholars are inspired by the intention models. A number of studies on entrepreneurial intention and its antecedents have been conducted as the starting point of the entrepreneurial process [10]. [11] explain that career choice is a voluntary and conscious process, therefore it can be analyzed. The applicability of intention models to the domain of entrepreneurship has been demonstrated by several scholars (eg. [12], [13]. As defined by [13] entrepreneurial intention is the intent to start a business, and/or to launch a new venture. As reported, several scholars done on entrepreneurial intention, its antecedent and determinant factors (eg. [5], [14],[15],[1]).

Several antecedents to entrepreneurial such as subjective norms, personality traits, satisfaction, and self-efficacy have been explored. For example, [15] found that subjective norms play a major role and influence on entrepreneurial intention among the business students in Bangalore. Meanwhile, examined the role of personality traits on entrepreneurial intention in Turkey. This effort resulted that personality traits have a positive effect on entrepreneurial intention among 480 graduate students in Turkey. Other research conducted by [1] presented that self-efficacy is significantly associated with entrepreneurial intention among 345 students in the Malaysian university. Given that knowledge of the mechanisms affecting the entrepreneurial intention behaviour link is still poor [16]; thus this study attempts to investigate on other possible antecedents of entrepreneurial intention such as entrepreneurial education and entrepreneurial implementation in the context of the tertiary level education in Malaysia. Therefore, it is hoped that the results of this study can provide a guide to solve the issue of unemployment among graduates in Malaysia.

\section{B. Entrepreneurial Education}

Entrepreneurship (entrepreneurial) education is the form of education designed for the learner to become an entrepreneur by using an approach to stimulate students to be curious and creative [17]. Traditionally, entrepreneurship education is defined as education that imparts skills needed to set up a new business [3]. It describes the scopes of lecturers, curriculum or programme that attempt to provide students with the necessary entrepreneurial competencies, knowledge and skills geared at the pursuit of an entrepreneurial career $[18,19]$. It refers to the conscious effort of an educator targeted at inculcating entrepreneurial skills in learners [20]. According to [21], knowledge learned and skills trained and developed during a semester taking the course is expected enable boosting students' motivation and attitude from inside to become an entrepreneur. As added by [22] entrepreneurship education is a process of instilling, growing, and forming students' entrepreneurial competence through improving knowledge obtained from and their experience and practical engagement in lectures. This effort revealed that entrepreneurial intention is indirectly affected by entrepreneurship education, with students' entrepreneurial motivation and attitude played a significant mediating effect.

[5] stated that entrepreneurial education can equip students with entrepreneurial skills and prepare them for an entrepreneurial career. Entrepreneurship education should be able to provide students with an understanding of a business purpose, structure and how the business interrelates with society and the economy [3]. For instance, presented that entrepreneurial education is generally effective for business students as well as for science and engineering students. In addition, [23] found a significant positive correlation between the students' success levels in the entrepreneurship class and their entrepreneurial intention. Other evidences also have shown that entrepreneurship education is effective at motivating students' entrepreneurial intention which culminates into performance of entrepreneurial behaviour [24]. Although learning experiences can nurture students to develop an innovative ability, the spirit of entrepreneurship, practical knowledge and competency; [5] claimed that there was a lack of understanding to the extent in which students' perceptions upon the quality of entrepreneurial education impacted their 
entrepreneurial intention. Given that, this study aims to reveal the impact of entrepreneurial education on entrepreneurial intention among students from one of the public university in the Northern Region of Malaysia. The

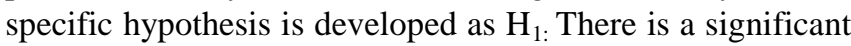
impact of entrepreneurial education on entrepreneurial intention among students in this public university.

\section{Entrepreneurial Implementation}

Entrepreneurial implementation suggests that intentions can be expressed through certain observable actions and behavioural responses to show commitment towards the achievement of entrepreneurial goals and aspirations [4]; thus, perceptions play a critical role in entrepreneurial education. If student has a positive perception towards entrepreneurial education, it is likely that the student will actively engage in the activities involved in the entrepreneurial education. This may show that the entrepreneurial education (programme) has been well implemented by the educators. As stated by [25] individuals with positive perception upon the entrepreneurial programme will perceive themselves as having what it takes to achieve the goals of the programme as it relates to the teaching and learning. Given that, perception of a student towards the multiple perspective of entrepreneurial education will largely determine the goals of what the student targets for himself. This target will shape the actions taken towards realizing the expected entrepreneurial outcome. Based on the perceptions of students towards the overall implementation upon entrepreneurial education in this selected university, this study attempts to explore the extent to which exposure to entrepreneurial implementation may create any impact on students' entrepreneurial intention in one of the Malaysian public university.

Based on the existing literature, few evidences have been reported on the link between entrepreneurial implementation and entrepreneurial intention. For example, [26] revealed that establishing entrepreneurship programme centers in institutions and designing entrepreneurial curriculum in line with market demand were among the strategies for effective implementation of entrepreneurship education and training in institutions of the higher learning in Nigeria. Entrepreneurship requires application of energy and passion towards the creation and implementation of new ideas and creative solutions [17]. As cited by [4], entrepreneurial implementation intention is defined as a volitional phase consisting of efforts to initiate an intended entrepreneurial behaviour. His conducted a study to examine the relationship between entrepreneurship education and entrepreneurial implementation and revealed that both variable are significantly correlated. He added that the variables of entrepreneurial implementation are developed based on previous studies [27-29].

However, in this current study, we seek to investigate the impact of entrepreneurial implementation on entrepreneurial intention. In other words, we attempt to reveal whether students' perception upon entrepreneurial education is well implemented by the educators or not. The good entrepreneurial education may lead to nowhere if the implementation was not as expected. Therefore, students' perception towards the implementation of entrepreneurial education is very important to be revealed. Further, the link between entrepreneurial implementation and entrepreneurial intention is very important to be explored since the results may become very fruitful and can contribute for a new knowledge to the existing literature. Given that, the second aims for this study is to examine the impact of entrepreneurial implementation on entrepreneurial intention among students from one of the public university in the Northern Region of Malaysia. The specific hypothesis is developed as $\mathrm{H}_{2:}$ There is a significant relationship between entrepreneurial implementation and entrepreneurial intention among students in this public university.

\section{METHODOLOGY}

The population of this study included all students from one of the public university located in the Northern Region of Malaysia. The data regarding entrepreneurial intention, entrepreneurial education and entrepreneurial implementation have been obtained from the perspective of the students (self-ratings). This study has utilized the survey method in order to get the required information. 488 students from various schools participated in this study. By focusing on the individual unit of analysis (students), the questionnaires have been distributed personally to the representatives from each school. Five (5) questions have been developed in order to obtain data regarding the demographic background for all respondents. Respondents are required to reveal their gender, age, race, year of study and whether they came from family who owned a business. Next, respondents' perception towards their entrepreneurial education and entrepreneurial implementation becomes the basis for understanding the level of their entrepreneurial intention. To obtain the information on respondents' entrepreneurial intention, the 9-items of [30] has been fully adapted. As for the independent variables; which are entrepreneurial education and entrepreneurial implementation, 9-items of measurement from [4] has been adopted. Based on a five-point scale with $1=$ strongly disagree, to $5=$ strongly agree; participants rated their degree of agreement towards the statements on entrepreneurial intention, entrepreneurial education as well as entrepreneurial implementation. Cronbach alpha values for entrepreneurial intention, entrepreneurial education and entrepreneurial implementation are reported at $0.783,0.923$ and 0.824 each. Therefore, the alpha values for all variables were in the acceptable scale reliabilities, ranged from 0.783 to 0.923 . According to [30], if the value exceeds alpha reliability of more than 0.70 , the questionnaires can be used for the actual study.

\section{RESULTS AND FINDINGS}

Out of 500 distributed questionnaires, only 488 usable questionnaires have been collected and analyzed, which bring the total of $96.7 \%$ for the response rate. The background of the respondents presented that more female respondents $(70.3 \%)$ than male respondents $(29.7 \%)$ have been participated in this study. Most of the respondents are 
International Conference on Recents Advancements in Engineering and Technology (ICRAET-18) |15th and 16th March 2019|Siddhartha Institute of Technology \& Sciences, Telangana, India.

in the ranged of age between 21 to 23 years old (59.4\%), while the least respondents came from the age above 26 years old (1\%). Most of respondents were Malays (67.6\%), followed by Chinese $(19.7 \%)$, Indian $(8.6 \%)$ and other races (4.1\%).

In term of year of study, $40.6 \%$ of the respondents were the first year students, followed by $20.7 \%$ were the second year student and $37.7 \%$ were the third year students. The remaining respondents were among the fourth year students $(0.6 \%)$ and other categories of students $(0.4 \%)$ such as the repeaters. To the extent of respondents came from family who owned a business, $34.4 \%$ of students stated 'yes' and the remaining $65.6 \%$ students stated 'no'.

Descriptive statistics for the mean score presented that mean values for entrepreneurial intention, entrepreneurial education and entrepreneurial implementation are reported at 3.64, 3.70 and 3.12. For both entrepreneurial intention and entrepreneurial education, the high mean scores of 3.64 and 3.70 showed that the distribution of the scores are skewed towards the agreement. Also, a high mean score for entrepreneurial implementation at 3.12 indicated that this university also has a moderately high level of entrepreneurial implementation. As presented in Table I, inter-correlations between entrepreneurial education and entrepreneurial implementation showed bivariate relationships with entrepreneurial intention among 488 participants in this study.

Table I: Inter-correlation between Variables

\begin{tabular}{|c|c|c|c|c|}
\hline Variables & $\mathbf{N}$ & 1 & 2 & 3 \\
\hline $\begin{array}{l}\text { Entrepreneurial } \\
\text { Intention }\end{array}$ & $8^{48}$ & - & & \\
\hline $\begin{array}{l}\text { 2. Entrepreneurial } \\
\text { Education }\end{array}$ & $8^{48}$ & ${ }^{*} .53 *$ & - & \\
\hline $\begin{array}{l}\text { 3. Entrepreneurial } \\
\text { Implementation }\end{array}$ & $8^{48}$ & ${ }^{*} .54 *$ & ${ }^{*} .64 *$ & - \\
\hline
\end{tabular}

$* *$ Correlation is significant at the 0.01 level (2-tailed).

The first correlation between entrepreneurial intention and entrepreneurial education is positively associated $(r=.53$, $\mathrm{p}=<.01$ ). Second, the correlation between entrepreneurial intention and entrepreneurial implementation is also positively associated $(\mathrm{r}=.54, \mathrm{p}=<.01)$. Similarly, the correlation between entrepreneurial education and entrepreneurial implementation is also positively associated $(\mathrm{r}=.64, \mathrm{p}=<.01)$.

Table II: Regression Analysis towards Entrepreneurial Intention

\begin{tabular}{|c|c|c|c|c|}
\hline \multirow[t]{2}{*}{ Predictors } & \begin{tabular}{|c|} 
Standardize \\
Coefficient
\end{tabular} & \multirow[t]{2}{*}{$\mathbf{T}$} & \multirow[t]{2}{*}{ Sig. } & \multirow[t]{2}{*}{$\mathbf{R}^{2}$} \\
\hline & Beta & & & \\
\hline $\begin{array}{l}\text { Entrepreneuria } \\
\text { 1 Education }\end{array}$ & 0.55 & $60^{14 .}$ & .00 & .300 \\
\hline $\begin{array}{r}\text { Entrepreneuria } \\
1 \text { Implementation }\end{array}$ & 0.52 & 41 & .00 & .269 \\
\hline
\end{tabular}

*Correlation is significant at the 0.01 level (2-tailed)

$* *$ Dependent Variable $=$ Entrepreneurial Intention

Linear regression analysis was undertaken to analyze the association of the independent variables and dependent variables in the study. Table II showed that entrepreneurial education is significantly related to entrepreneurial intention at $\beta=0.55$ and $\mathrm{p}=0.00$; with moderate adjusted $\mathrm{R}^{2}$ (30.0\%). Therefore, $\mathrm{H}_{1}$ : There is a significant impact of entrepreneurial education on entrepreneurial intention among students in this public university is accepted in this study. Next, Table II indicated that entrepreneurial implementation is significantly related to entrepreneurial intention at $\beta=0.52$ and $p=0.00$; with moderate adjusted $\mathrm{R}^{2}(26.9 \%)$. Hence, $\mathrm{H}_{2}$ : There is a significant impact of entrepreneurial implementation on entrepreneurial intention among students in this public university is also accepted in this study.

\section{DISCUSSIONS}

The results of this study confirm the findings of the previous studies in terms of significant relationship between entrepreneurial intention and two variables, namely entrepreneurial education and education implementation. The findings on the impact of entrepreneurial education on entrepreneurial intention is inconsistent with the previous studies $[7,8]$. The findings also prove that entrepreneurial education plays as a main platform to increase the human development in order to produce more entrepreneurs among students [4]. In this institution, the students have high level of agreement towards entrepreneurial education and entrepreneurial intention as reported in the previous section (mean at 3.70 and 3.64 respectively). To ensure the level of both variables can be remained, the awareness campaigns of entrepreneurship to educators, policy makers, and all students in this institution need to be enforced. The results regarding the relationship between entrepreneurial education and entrepreneurial intention is consistent with the findings of [22] who presented that entrepreneurial education created a positive impact on entrepreneurial intention among college students in Indonesia. The specific entrepreneurial courses (eg. business plan, entrepreneurial finance, marketing, field projects, etc.) should be remained in the programmes to develop entrepreneurial knowledge and skills.

This study also explored the impact of entrepreneurial implementation on entrepreneurial intention, and found that both variables are significantly related among the undergraduate students in this public university. Hence, this study suggests that providing university students with more experience-based entrepreneurial learning opportunities leads to the development of implementation intentions among them which may able to increase their propensity to engage in entrepreneurial activities. Based on this findings, this university should continue its effort to cultivate an enterprise culture across faculties (schools) to influence the students' decisions towards becoming the job creator. It is important to present an interesting image of entrepreneurship as one of the career choices once students have graduated. Therefore, this may help the nation to reduce the unemployment rate among the graduates. Last but not least, even though individuals received relevant knowledge and skills through the entrepreneurial education 
as well as acceptable level of entrepreneurial implementation towards entrepreneurship in the university, they still must have high level of interest and desire to get into the entrepreneurial field.

Future researchers are suggested to collect a longitudinal data from a larger sample which it would provide more valid evidence to support the findings of the current study since we done on a cross-sectional approach to do the data collection and only limited to a single university. Since the current study employed the survey method, the future studies could consider to the use of other tools, such as interviews and focus groups, to collect the required data for measuring entrepreneurial education and entrepreneurial implementation as well as entrepreneurial intention.

\section{ACKNOWLEDGMENT}

The authors would like to acknowledge the support from the GIG Economy under a grant number of 9022-0005 from the Ministry of Education Malaysia.

\section{REFERENCES}

1. Saraih UN, Ain Zuraini ZA, Suhana AM, Tunku Salha TA, Sharmini A, M. Harith Amlus. The influence of selfefficacy on entrepreneurial intention among engineering students. MATEC Web Conf. 2018;150:1-6.

2. Krueger Jr NF, Reilly MD, Carsrud AL. Competing models of entrepreneurial intentions. J Bus Ventur. 2000;15(5-6):411-32.

3. Rahim HL, Kadir MABA, Abidin ZZ, Junid J, Kamaruddin LM, Lajin NFM, et al. Entrepreneurship education in Malaysia: A critical review. J Technol Manag Bus. 2015;2(2):1-11.

4. Olokundun MA. Perceptions of students on entrepreneurship education and entrepreneurial intentions in selected Nigerian universities. Covenant University; 2017.

5. Hsiung T-L. Satisfaction with Entrepreneurial Education and Entrepreneurial Intention: The Moderating Role of Internal Locus of Control. Int $J$ Educ Res. 2018;6(4):139-46.

6. Rodrigues RG, Raposo M, Ferreira J, Paco A Do. Entrepreneurship education and the propensity for business creation: Testing a structural model. Int $\mathrm{J}$ Entrep Small Bus. 2010;9(1):58-73.

7. Graevenitz G Von, Harhoff D, Weber R. The effects of entrepreneurship education. $\mathrm{J}$ Econ Behav Organ. 2010;76(1):90.

8. Su-Chang Chen, Hsi-Chi Hsiao, Jen-Chia Chang, ChunMei Chou, Chin-Pin Chen C-HS. Can the entrepreneurship course improve the entrepreneurial intentions of students? Int Entrep Manag J. 2015;11(3):557-69.

9. Hattab H. Impact of entrepreneurship education on entrepreneurial intentions of university students in Egypt. J Entrep. 2014;23(1):1-18.

10. Evan J. D, Jason R. F. Intrapreneurial intentions versus entrepreneurial intentions: Distinct constructs with different antecedents. Small Bus Econ An Entrep J. 2013;41(1):115-32.

11. Krueger NF, Michael DR, Carsrud AL. Competing models of entrepreneurial intentions. J Bus Ventur. 2000;15(5-6):411-32.

12. Kautonen T, van Gelderen M, Fink M. Robustness of the theory of planned behavior in predicting entrepreneurial intentions and actions. Entrep Theory Pract. 2015;39(3):655-74.
13. Krueger NF, Reilly MD, L. CA. Competing models of entrepreneurial intentions»,. J Bus Ventur. 2000;19(1):728.

14. Karabulut AT. Personality Traits on Entrepreneurial Intention. Procedia - Soc Behav Sci. 2016;

15. Krithika J, Venkatachalam B. A Study on impact of subjective norms on entrepreneurial intention among the business students in Bangalore. IOSR J Bus Manag. 2014;16(5):48-50.

16. Liñán F, Fayolle A. A systematic literature review on entrepreneurial intentions: citation, thematic analyses, and research agenda. Int Entrep Manag J. 2015;11(4):907-33.

17. Anaele EO, Adelakun OA, Dem II, Barfa GI. Strategies for revitalizing the implementation of entrepreneurship education in technical, vocational education and training (TVET) to enhance self-employment in Nigeria. Br J Educ. 2014;2(4):50-62.

18. Keat OY, Christopher S, Meyer D. Inclination towards entrepreneurship among university students: An empirical study of Malaysian university students. Int J Bus Soc Sci. 2011;2(4):206-20.

19. Ekpoh UI, Edet AO. Entrepreneurship education and career intentions of tertiary educationstudents in Akwa Ibom and Cross River States, Nigeria. Int Educ Stud. $2011 ; 4(1): 172-8$.

20. Moses CL, Olokundun MA, Akinbode M, Agboola M, Inelo F. Entrepreneurship education and entrepreneurial intentions: The moderating role of passion. Soc Sci. 2016;11(5):645-53.

21. Raposo M, Paço A. Entrepreneurship education : Relationship between education. Psicothema. 2011;23(3):453-7.

22. Mahendra AM, Djatmika ET, Hermawan A. The effect of entrepreneurship education on entrepreneurial intention mediated by motivation and attitude among management students, State University of Malang, Indonesia. Int Educ Stud. 2017;10(9):61-9.

23. Doğan E. The effect of entrepreneurship education on entrepreneurial intentions of university students in Turkey. Ekonom ve İstatistik Say1. 2015;23:79-93.

24. Izedonmi PF, Okafor C. The effect of entrepreneurship education on students' entrepreneurial intentions. Glob J Manag Bus Res. 2010;10(6):49-60.

25. Moy JWH, Luk VWM, Wright PC. Perceptions of entrepreneurship as a career: Views of young people in Hong Kong. Equal Oppor Int. 2003;22(4):16-40.

26. Asiyai RI. Strategies towards effective implementation of entrepreneurship education in higher education for global competiveness and wealth. J Emerg Trends Educ Res Policy Stud. 2013;5(1):41-8.

27. Albornoz-Pardo C. Is business creation the mean or the end of entrepreneurship education? A multiple case study exploring teaching goals in entrepreneurship education. J Technol Manag Innov. 2013;8(1):1-10.

28. Diaconu M. Technological innovation : Concept, process , typology and implications in the economy. Theor Appl Econ. 2011;10(563):127-44.

29. Lee SH, Wong PK. An exploratory study of technopreneurial intentions: A career anchor perspective. J Bus Ventur. 2004;19(1):7-28.

30. Nurul I, Stein K. Determinants of entrepreneurial intention: The case of Norwegian students. ,. Gadjah Mada Int J Bus. 2003;5(1):79-95

31. Nunnaly JC. Psychometric theory. 2nd ed. New York, United States: New York: McGraw-Hill; 1978. 701 p. 